\title{
Quantitation Type Dimension
}

National Cancer Institute

\section{Source}

National Cancer Institute. Quantitation Type Dimension. NCI Thesaurus. Code C44186.

An ordered list of quantitationTypes. 